\title{
Usage of ICT by the Students in Higher Secondary Schools of Jammu and Kashmir
}

\author{
Farhat Bashir, Dr. Mujibul Hassan Siddiqui \\ Department of Education, Aligarh Muslim University. Aligarh India
}

\begin{abstract}
Information and Communication Technology originally is applied to serve as a means of improving efficiency in the educational process. In the present study an attempt was made to check the difference in the usage of ICT between the boy and girl students of Higher Secondary School of Jammu \& Kashmir. The sample of the study consisted 100 students (50 boys and 50 girls) selected by random sampling technique from Higher Secondary School of Kashmir. The questionnaire was administered for collecting the data which was constructed by the present investigator. The data was analyzed with the help of percentage and was represented by the graph. The finding of the study shows that the usage of ICT by the students in the Higher Secondary Schools of Jammu and Kashmir is very low. The finding(s) also reveal that the usage of ICT by the boy students is higher as compared to that of girl students.
\end{abstract}

Keywords: Higher secondary students, ICT, Usage.

\section{Introduction}

Education is the acquisition of knowledge or information that empowers a person towards a better and higher way of life. Its field is so wide that all activities and experience are embraced in its sphere of work. The process of education involves the transfer of communication of knowledge and skills from one point (source) to another (receiver). During the recent past this process was dependent upon the Chalk and Talk method, but now a drastic change has undergone and Smart Classrooms (fully well equipped electronic web) have been developed.

During the past decade efforts to integrate the Information and Communication Technology (ICT) in most aspects of school practice have received a good deal of attention in the educational system. ICT is becoming an essential tool in our everyday life and also a common tool for teaching and learning process not only in schools but also in training colleges. Various researches have shown that teachers can use ICT to deliver lectures more efficiently and effectively in classrooms and pupil can learn better .[1] It is also important to keep in mind that ICTs in education are a potential double-edged sword - while ICTs offer educators, tools to extend education to hitherto inaccessible geographic regions, and to deprived children and empower teachers and students through information, there is also the danger that such technologies may further widen the gap between the educational haves and have-nots. However, technology is only a tool and the success of ICTs in enhancing the delivery of quality education to the needy, without widening the gap, will depend largely on policy level interventions that are directed toward how ICTs must be deployed in school education. It is widely accepted that competence in handling ICT is an important asset and an urgent requirement for citizens in modern societies. It is also believed that ICT in schools will enhance subject learning. At secondary school level ICTs should be adopted as a matter of urgency to enable teachers and learners to access this new direction in Internet technology and application delivery. [2]

ICT has its potential in schools, in the teaching of subjects, in examinations, in research, in systemic reforms, and above all, in teacher education, overcoming the conventional problems of scale and reach through online, anytime, anywhere.ICT has the potential to improve the quality of life by providing new tools for improving access to information and knowledge management as well as sharing. These days the term information and communication technology (ICT) has come to mean all technical means used to handle information and aid communication, including computer and network hardware as well as necessary software. [3]

The progress and development of any nation in the world mainly depend upon its educational system. Traditionally, our educational system has been almost entirely based on the teacher-centered approach . But now, there is a gradual but definite shift away from this paradigm towards a more student-centered approach. This is due to the influence of Educational Technology and the current Information and Communication Technology (ICT) explosion. Various recent studies have revealed that women are progressing and education is becoming more and more accessible to them [4], it is yet to be established that they get equal opportunities in the process of getting education. Information and Communication Technologies (ICTs) have influenced nearly every area of our society. Unfortunately, they have not yet succeeded in transforming our concept and practices 
of teaching and learning. Modern Technology seems to have influenced every area of our society, but it has had very little effect on our conceptions of teaching and learning [5] various studies have shown that ICT is not used by adequate women students.

Students studying at secondary school level are adolescents. As adolescents are the future of tomorrow, if their energies are channelized in right direction; they can bring change wherever they go. This change brought by ICTs is most promising aid in the field of education, which plays a crucial role in accelerating and uplifting the quality of education at higher secondary school level. ICT acts as a powerful force for change in society and citizen should have an understanding of the social, ethical legal and economic implications of its use, including how to use ICT safely and responsibly. Increased capability in the use of ICT supports initiatives and independent learning, as pupils are able to make informed judgment about when and where to use ICT to enhance their learning and the quality of their work. From the above evident discussion no research work has been done on availability of ICT facilities and usage in secondary school level. As a result higher secondary schools are selected as a target group and decision was made to study the usage of ICT in Higher Secondary Schools of Jammu and Kashmir study.

\section{Objectives}

1. To study the usage of ICT by the higher secondary school students of Jammu and Kashmir.

2. To find out the difference in the usage of ICT among the boy and girl students of higher secondary schools of Jammu and Kashmir.

\subsection{Area of the study}

\section{Methodology}

The present study is based on the survey carried out by the investigator (2011) in Jammu \& Kashmir which is the northern most state of India situated between 32.15 degree and 37.05 degree North latitude and 72.35 degree and 82.20 degree East longitude the total area of the state is $222,236 \mathrm{~km}$. The population of state according to 2001 census is 10,143700. (Male 536,0926) and (Female 47,82,774). There are several private and public schools approximately 14,938 schools which include Primary Elementary and higher secondary schools.

\subsection{Sample of the study}

The population selected for the present research work comprises of higher secondary school students of class $9^{\text {th }}, 10^{\text {th }}, 11$ th $\& 12^{\text {th }}$ standard, of Kashmir division. The sample extracted out of the population consists of total number of 100 students $(\mathrm{N}=100)$ out of which 50 were boys and 50 were girls. The sample break-up is as under:

FIG.1

Sample Break-up

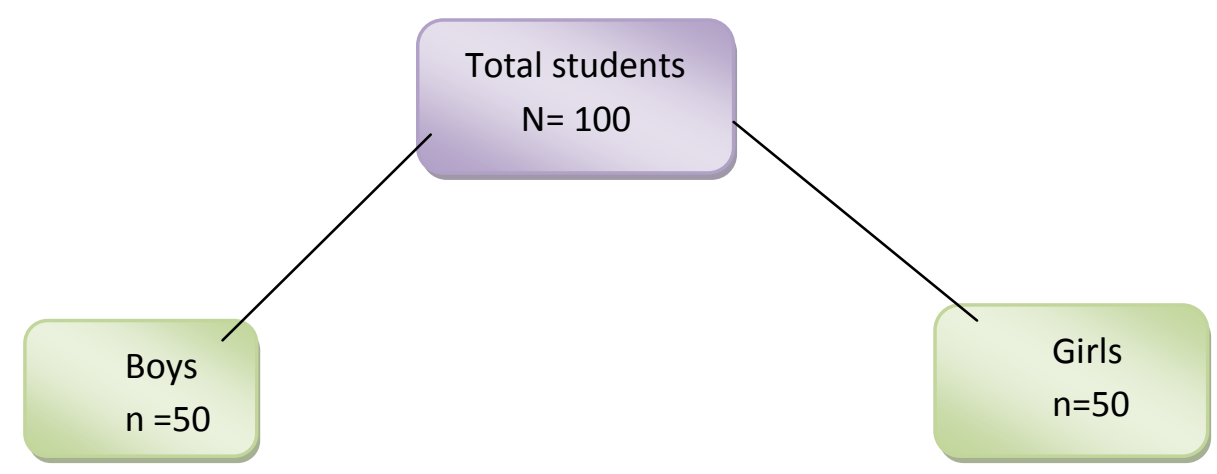

\subsection{Tool used}

To study the usage of ICT, appropriate tool was not available. Hence a questionnaire was developed to fulfill the need. The questionnaire consists of 20 questions designed for both, boys as well as girls by the investigator in order to check the usage of ICT at Higher Secondary level. Responses were marked under two categories 'Yes' and 'No'. For the sake of constructing questionnaire, the following steps were followed:

Step-I: It included the preparation of blue print of the questionnaire. All aspects related to ICT usage in the schools were taken into considerations.

Step-II: According to the blue print, twenty ICT gadgets were selected and the questionnaire was framed.

Step-III: The twenty ICT gadgets (for students) were selected; some of gadgets were eliminated after consulting the several judges. 


\subsection{Statistical Technique used}

The analysis of data was done by using statistical technique percentage which was chosen only after it was found that they are most appropriate and compatible for the collected data.

\subsection{Analysis}

\section{Analysis and Interpretation}

The data have been critically analyzed and reported through textual discussions and tabular form. The textual discussions have been used to point out generalizations and significant interpretations. The table and a graph have been used to check the usage of ICT by the male students is more than that of the female students. It is constructed in such a way that it is self explanatory. Thus in order to study the usage of ICT in Higher Secondary Level in Kashmir and its usage among boys and girls, percentage and graph were taken as the statistical tool.

Table 1

Usage of ICT by the higher secondary schools students $(N=100)$

\begin{tabular}{|c|c|c|c|c|c|c|}
\hline \multirow[t]{2}{*}{ ICT gadgets } & \multirow{2}{*}{$\begin{array}{c}\text { Respons } \\
\text { e }\end{array}$} & \multicolumn{2}{|c|}{ Usage of ICT by Boys } & \multicolumn{2}{|c|}{$\begin{array}{l}\text { Usage of ICT by } \\
\text { Girls }\end{array}$} & \multirow{2}{*}{$\begin{array}{c}\text { Total Usage } \\
\text { of ICT by } \\
\text { students }\end{array}$} \\
\hline & & Number & Percent & Number & Percent & \\
\hline Computer & Yes & 43 & $86.0 \%$ & 23 & $46.0 \%$ & $66.0 \%$ \\
\hline Projector & Yes & 7 & $14.0 \%$ & 4 & $8.0 \%$ & $11.0 \%$ \\
\hline Microphone & Yes & 50 & $100.0 \%$ & 47 & $94.0 \%$ & $97.0 \%$ \\
\hline online learning & Yes & 0 & $0 \%$ & 0 & $0 \%$ & $0 \%$ \\
\hline Epidiascope & Yes & 0 & $0 \%$ & 0 & $0 \%$ & $.0 \%$ \\
\hline Globe & Yes & 50 & $100.0 \%$ & 50 & $100.0 \%$ & $100.0 \%$ \\
\hline Calculator & Yes & 29 & $58.0 \%$ & 19 & $38.0 \%$ & $48.0 \%$ \\
\hline Internet & Yes & 12 & $24.0 \%$ & 0 & $.0 \%$ & $12.0 \%$ \\
\hline Radio & Yes & 0 & $0 \%$ & 0 & $0 \%$ & $0 \%$ \\
\hline working-model & Yes & 0 & $0 \%$ & 0 & $0 \%$ & $0 \%$ \\
\hline TV & Yes & 0 & $0 \%$ & 0 & $0 \%$ & $0 \%$ \\
\hline Newspaper & Yes & 8 & $16.0 \%$ & 0 & $.0 \%$ & $8.0 \%$ \\
\hline Microscope & Yes & 29 & $58.0 \%$ & 19 & $38.0 \%$ & $48.0 \%$ \\
\hline Slide & Yes & 29 & $58.0 \%$ & 19 & $38.0 \%$ & $48.0 \%$ \\
\hline Laptops & Yes & 0 & $0 \%$ & 0 & $0 \%$ & $0.0 \%$ \\
\hline tape recorder & Yes & 7 & $14.0 \%$ & 0 & $.0 \%$ & $7.0 \%$ \\
\hline L.C.D & Yes & 0 & $0 \%$ & 0 & $0 \%$ & $0 \%$ \\
\hline white-boards & Yes & 39 & $78.0 \%$ & 13 & $26.0 \%$ & $52.0 \%$ \\
\hline $\begin{array}{l}\text { electronic- } \\
\text { boards }\end{array}$ & Yes & 0 & $0 \%$ & 0 & $0 \%$ & $0 \%$ \\
\hline Charts & Yes & 25 & $50 \%$ & 25 & $50 \%$ & $50 \%$ \\
\hline
\end{tabular}

\section{(Source: generated by field work)}

\subsection{Interpretation of the Result}

The table clearly depicts the usage of ICT gadgets by boys, like computer (86\%), projector (14\%), calculator(58\%), internet (24\%), newspaper (16\%), microscope, slides(58\%),tape-recorder(14\%), whiteboard(78\%), microphones, globe, charts (100\%), on-line learning, epidiascope, radio, working-models, T.V, laptop, L.C.D, electronic-boards (0\%), where as girls use computer(46\%), projector(8\%), microphone(94\%), globe, chart(100\%), calculator, microscope, slides (38\%), white-boards(26\%)on-line learning, epidiascope, internet, radio, working-models, T.V, newspaper, laptop, tape-recorder, L.C.D, electronic-boards (0\%). The table also reveals the total usage of ICT gadgets by the students like computer (66\%), projector (11\%), microphone(97\%), globe $(100 \%)$, calculator $(48 \%)$, internet(12\%), newspaper(8\%), microscope, slide( $48 \%)$, tape-recorder(7\%), white-board(52\%), charts(25\%)and all the students responded that do not use ICT gadgets like radio, working models, T.V, laptops, LCD, and electronic-boards. The graphical representation of the data shows that the boys use ICT gadgets more than that of the girls 


\section{FIG.2}

Graph showing the ICT usage comparison between boys and girls.

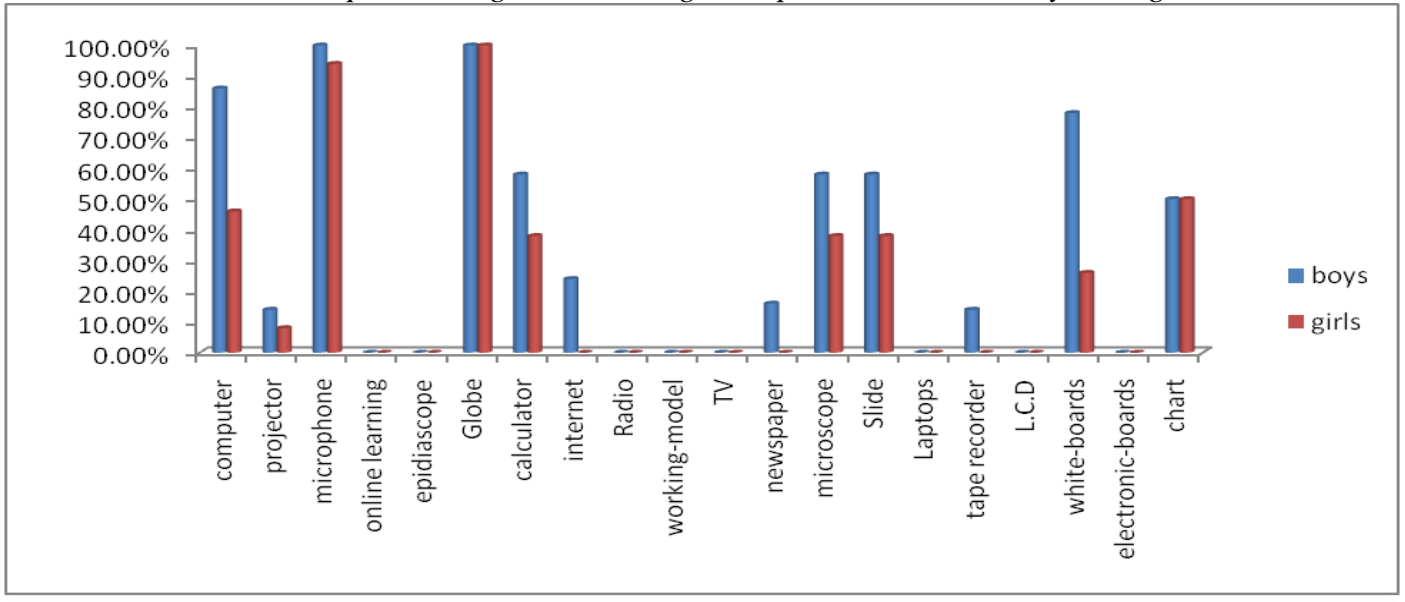

\section{Discussion}

The detailed study of the data revealed the low usage of ICT by the girl students as compared to boy students. As the boys use (86\%) computer where as girls use it only (46\%), usage of projector is (7\%)by boys and $(4 \%)$ by girls, the other ICT gadget like microphones (50\%) and (47\%)calculator, microscope, slide (58\%) and $(38 \%)$, white-boards $(78 \%)$ and $(26 \%)$ respectively. Some of the ICTs like tape-recorders, newspapers and internet are only used by the boys, as no girl students responded in positive about the usage of these ICTs. As the present study got under way, it was realized that there were limited experiences in the use of ICTs for girl literacy in the region/area of the study. It is quite evident from the data that expensive and latest ICTs for example on-line learning, LCD, epidiascope ,working models, laptops and electronic boards etc are not used by the students. The probable cause for this may be incompetency to use such technological devices and lack of interest and low participation by them. The journey towards female inclusion in the general field of science and technology has been a long and difficult one. The female students are opined that they do not use internet, newspaper and tape recorders in the school. For the most part, women and girls are particularly vulnerable to constraints especially as more than two thirds of the world's illiterates are women, and they comprise 60 percent of rural populations where infrastructure is weakest. However, women's access to ICT and their effective use of it are constrained by factors that go beyond issues of technological infrastructure and socioeconomic environment [6]. From the data is quite evident that boys use ICT more as compared to girls. The very low usage of ICT by the girl students might be due to the fact that the female students have fewer opportunities than that of the male students. Confirmation of this can be found in the statement of the Secretary General of the United Nations in his speech at the world summit on the information society in Geneva in December 2003 in which he said there is "a gender divides, with women and girls enjoying less access to information and technology than men and boys". There must be another reason that the boys are much aware of ICTs than that of girls and they have more opportunities to access ICT. [7] Study revealed that the most of female students use computers only once or twice in a week, he found that 6 percent of female students did not use computers at all. The result indicates that the male students have higher opportunities to access computers in other places except school and home than that of female students. Socially and culturally constructed gender roles and relationships play a crucial role in shaping and limiting the capacity of women and girls to participate on equal terms in the information society [8].

\section{Conclusion}

ICT has revolutionized the entire concept of education, learning and research by offering new opportunities and challenges in creations and dissemination of information.ICT can be used as a tool to solve different types of problems in development of students thinking or in creative activities, to support collaboration among all participants of learning process as a standard component of educational environment. One of the most commonly cited reasons for using ICTs in the schools has been to prepare the current generation of students for a workplace where ICTs, particularly computers, the internet and related technologies are becoming more and more ubiquitous. The use of ICT especially computers and internet technologies- enables new ways of teaching and learning rather than simply allow teachers and students to do what they have done before in a better way. These new ways of teaching and learning are underpinned by constructivist theories of learning and constitute a shift from a teacher-centered pedagogy-in its worst form characterized by memorization and rote learning-to one that is learner centered. Achieving gender equality in ICT requires more than mainstreaming gender concerns 
into the ICT arena. It requires serious commitment and political will. The aim is both to ensure women's access to the benefits of ICT and to make ICT a central tool in women's empowerment and the promotion of gender equality (Munyua, 2005). Hence, it is imperative to overcome the challenge of illiteracy before women can benefit from ICT, though use of audio and video technologies have been known to overcome the problem of women's illiteracy to a limited extent. If gender dimensions of ICT in terms of access and use, capacity building and employment opportunities, and potential for empowerment are explicitly identified and addressed, ICT can be a powerful catalyst for political and social empowerment of women and the promotion of gender capacity. There is, therefore, the need to develop gender specific indicators of ICT, and mainstream and monitor gender perspectives in all ICT initiatives.

\section{References}

[1] DOMA,Deoraj.(2009) International Diploma in Educational planning and Administration. National University of Education Planning and Administration. New Delhi.

[2] Le Roux CJB and N. Evans (2011) can cloud computing bridge the digital divide in South African secondary education? Information Development 2011 27:109.

[3] Rubab, Seemin. (2011) ICT \& Women Empowerment case study on small scale service providers.NIT Srinagar Jammu and Kashmir.

[4] Censes report, Government of India (2011)

[5] Schank,R.(2007).Teaching in the new Era.In C Crawford,R. Carlsen,K.McFerrin, Price,\& R.Weber (Eds.),proceeding of society for information Technology and Teacher Education International Conference 2007 (keynote). Chesapeake, VA:AACE

[6] Tchombe, T.M.S. (2008). Gender and Psycho-pedagogical Implications for Cognitive Growth through Access to Information and Communication Technologies. In K. Toure, T.M.S. Tchombe, \& T. Karsenti (Eds.), ICT and Changing Mindsets in Education. Bamenda, Cameroon: Langaa; Bamako, Mali: ERNWACA / ROCARE

[7] Aypay Ahmet, (2010) Information and communication technology ICT usage and achievements of Turkish students in PISA 2006. The Turkish journal of Education Technology-April 2010 volume9 issue-2

[8] Munyua, A.W. (2005). Positioning for Impact: Women and ICT Policy Making. In F. Etta, \& F.Elder (Eds.), At the Crossroads: ICT Policymaking in East Africa (Chapter 13). Nairobi, Kenya:East African Educational Publishers; IDRC 